\title{
Substantive masive și abstracte pluralizate în româna veche
}

\author{
Gabriela Pană Dindelegan* \\ Facultatea de Litere, Universitatea din București, Str. Edgar Quinet 5-7, Sector 1, 010017 București, România \\ Institutul de Lingvistică „Iorgu Iordan - Al. Rosetti”, Calea 13 Septembrie 13, 050711 București, România
}

\section{Despre articol}

Istoric:

Primit 8 mai 2017

Acceptat 3 iunie 2017

Publicat 30 septembrie 2017

Cuvinte-cheie:

română veche

masiv

abstract

pluralizare

plural lexical

\begin{abstract}
Rezumat
În urma examinării unui corpus bogat de limbă română veche, autorul ajunge la concluzia că fenomenul 'pluralizării' substantivelor masive și al celor abstracte este extrem de frecvent în româna veche. Efectele semantice ale pluralizării sînt asemănătoare pentru masive și abstracte, constînd în apariția unor varietăți semantice denotative și/sau conotative. Din ansamblul desinențelor de plural, dacoromâna și-a specializat una (desinența -uri) pentru pluralizarea masivelor. Evoluția desinenței - uri evidențiază un proces special, de convertire a unui semn gramatical (de plural) într-unul lexical (aşa-numitele 'plurale lexicale'). Deși 'pluralele lexicale' apar, izolat, și în alte limbi romanice, nicăieri nu au luat extinderea și regularitatea din română.
\end{abstract}

\section{Introducere}

Substantivele masive şi abstracte au caracteristici semantice şi morfosintactice comune, ceea ce explică participarea lor la fenomene comune (vezi 'pluralizarea' și efectele ei), dar și tratarea lor împreună (ca în articolul de față).

Scopul articolului de față este să examineze, pe baza unui corpus bogat de limbă română veche (1560_ 1780), fenomenul pluralizării substantivelor masive și abstracte, să surprindă caracteristicile lui în româna veche, precum și efectele semantice și gramaticale.

\section{Substantive 'masive'}

\subsection{Trăsături caracteristice}

Trăsătura inerentă [+masiv] influențează gramatica substantivului, în sensul că substantivele 'masive' se disting de cele prototipice atît din punct de vedere flexionar (Nedelcu, 2013, p. 260-261), cît și morfosintactic (Pană Dindelegan, 2016b, p. 324-332). O caracteristică flexionară a masivelor este apartenența la clasa non-numărabilelor, majoritatea substantivelor masive fiind defective de plural [substantive singularia tantum (1a-d)] și, numai cu totul izolat, și defective de singular [substantive pluralia tantum (2a-b)].

(1) a. unulu amu auru dăruindu, și altulu argintu, e altulu păine $\left(\mathrm{CC}^{2} .1581,321 / 1\right)$

b. Şi v-am dat voauo grîu și vin şi unt (CLRV, 172 $\left.{ }^{\mathrm{r}}\right)$

c. ca să nu mai aducă sînge de capră și de vițel și cenușe de juncu (Ev.1642, 317)

d. Miiare, lapte din pămînt vor izvorî (DPar.1683, III/134²)

(2) a. era tremişi în cetate să cumpere bucate $\left(\mathrm{CC}^{2} .1581,151\right)$

b. Sile-au trimis de sațîu merinde (DPV.1673, 541)

*Adresă de corespondență: g_dindele@yahoo.com. 
O altă trăsătură a masivelor, caracterizînd româna în ansamblul Romaniei, privește posibilitatea de a apărea în poziții argumentale fără articol sau, altfel spus, în construcții cu grupuri nominale „nude” [vezi (3a)]. Ca și spaniola, portugheza și sudul Italo-Romaniei (vezi Ramat \& Ricca, 2016, p. 52-53), româna nu a dezvoltat un articol partitiv. Spre deosebire de româna modernă, în româna veche, alături de construcțiile fără articol (3a), sînt înregistrate și construcții cu de partitiv în poziții argumentale [(3b-c); Pană Dindelegan, 2016a, p. 330-331], dispărute ulterior din uzul lingvistic standard.

(3) a. Cerșu elu să bea apă $\left(\mathrm{CC}^{2} .1581,158\right)$

b. Să bea de apa ce-i voi da eu (CazV.1643, 158 $)$

c. Că unii aleg de bucate: un fealiu de bucate mănîncă $\left(\mathrm{CC}^{1} .1567,194^{\mathrm{r}}\right)$

\subsection{Pluralizarea masivelor}

În mod curent, pluralizarea masivelor antrenează modificări de sens, ducînd, implicit, și la 'demasificare' (4a). Uneori, pluralizarea poate interveni în cadrul unei variații de gen [marmurile F//N.PL $_{\text {N }}$ varmurii ${ }_{\mathrm{M} . \mathrm{PL}}$ $(4 b-c)]$, efectul semantico-gramatical fiind același: schimbarea de sens și, implicit, 'demasificarea'.

(4) a. să-șu ia pre cale numai un toiagu, nece bucate, nece pîine, nece pre brăne arămi ${ }^{1}$ (СТ.1560-1, $79^{\mathrm{v}}$ )

b. daca s-au luat marmurile de pre gropniță au luminatu soarele ș-acolo (Cron.1689, 98)

c. stîlpii și marmurii (DVs.1682-6, 96 ${ }^{\mathrm{r}}$ )

Din ansamblul desinențelor de plural, una se specializează pentru procesul de 'pluralizare' a masivelor, ataşîndu-se atît la femininele masive, cît și la neutrele masive. Este vorba de finala -uri, care, ataşată substantivului masiv, asigură pluralizarea și, implicit, schimbarea sensului ${ }^{2}$. Sub aspect funcțional, în asemenea utilizări, desinența -uri se apropie de un sufix lexical, asigurînd schimbarea nu numai a trăsăturilor flexionare, ci și a sensului cuvîntului. Fenomenul este în exclusivitate nord-dunărean ${ }^{3}$ și datează de la începutul secolului al XVII-lea, prima atestare fiind de la 1620 [Frâncu, 1982; (5a)]; ulterior, exemplele se înmulțesc și se diversifică ( $5 b-j)$. Se disting următoarele situații de 'pluralizare':

(i) - uri se atașează unor radicale masive din clasa femininelor ${ }^{4}$, avînd drept efect fie apariţia unui sens denotativ nou, cel de „sorturi, varietăţi dintr-o anumită materie” ( $5 a-j)$, fie a unei valori conotative de tip depreciativ (6). Dar în timp ce prima categorie este veche în limbă (începutul secolului al XVII-lea), cea de a doua aparține românei moderne ${ }^{5}$.

(5) a. Și carne $e_{1}$ o dede tătarilor de o $m<\hat{\imath}>n c a r a ̆$, și ziseră că $<$ este $>$ mai dulce de toate cărnurile pre $_{2}$ lume $^{6}\left(\mathrm{~A} .1620,24^{\mathrm{v}}\right)$

b. Toate cărnurile sărate, cum spete, limbi, cîrnați, păstrămi (CBuc.1749, 52 )

c. îvvățătură de a face dulcețuri (CBuc.1749, 59 $)$

d. cînd va fi aproape de fiert, pune-i o mină de erburi tocate (CBuc. 1749, $6^{\mathrm{r}}$ )

e. călțun cu sîrmă și cu alte mătăsuri (CDicț.1691-7, 136)

f. îvvățătură de a face multe feliuri de sălături (CBuc.1749, 49²)

g. căci sîngiuri multe ai vărsat preste pămînt înaintea Mea (вв.1688, 302/XXII)

\footnotetext{
${ }^{1}$ Să se facă diferența între forma de plural a substantivului masiv și forma etimologică de singular arame (darul carele de la ei veți lua: aur, argint, arame, PO.1582, 190; poarta cea de arame, Ev.1642, 209).

${ }^{2}$ În Maiden (2014, p. 41), se vorbește de funcția nouă a lui -uri, mai degrabă „derivațională” decît gramaticală.

${ }^{3}$ Maiden (2015, p. 46) observă că, spre deosebire de dacoromână, în dialectele sud-dunărene (meglenoromână și aromână), nu există nici o corelație între extinderea lui -uri la pluralul femininelor și semantica masivă, -uri apărînd și pentru substantive non-masive.

${ }^{4}$ Vezi lista completă a femininelor cu -uri la Maiden (2015, p. 44-45).

${ }^{5}$ Pentru româna modernă, vezi descriere detaliată la Avram (2003-2004).

${ }^{6}$ În același exemplu, apar cele două forme diferite, corespunzătoare la sensuri diferite și, implicit, la unități lexicale diferite.
} 
h. țîitoare de unsoruri (CDicț.1691-7,321)

i. Și să mănînce cu adzîmă nedospită și cu verdețuri amară (Cron.1689, 47)

j. baie de zoaie, scăldătoare de zoiuri (CDicț.1691-7,493)

(6) delicatețuri $(\leftarrow$ delicatețe), gentilețuri $(\leftarrow$ gentilețe $)$, politețuri $(\leftarrow$ politețe $)$, străinătăţuri $(\leftarrow$ străinătate $)$, tandrețiri $(\leftarrow$ tandrețe $)$

(ii) -uri se atașează unor radicale masive din clasa neutrelor, avînd drept efect apariția unui sens denotativ diferit: (i) „obiecte făcute din materialul avut în vedere” (7a-c); (ii) „sorturi” (7d).

(7) a. Au nu cu arginture [„,bani din argint”] te-ai tocmitu cu mine? (ст.1560-1, 42 ${ }^{\mathrm{v}}$ )

b. Cînd vei vrea să speli arginturile ["obiecte din argint"] (CBuc.1749, 62 ${ }^{\mathrm{r}}$ )

c. Untul de ceară (...) păstrează foarte bine metalurile [„obiecte din metal”] de rugină (CBuc.1749, 63 ${ }^{\mathrm{v}}$ )

d. să să bea ca și alte vinuri [,sorturi de vin”] noao (CBuc.1749, 53 $)$

Fenomene similare de 'plural lexical' au fost semnalate și în alte varietăți romanice (asturiană, leoneză, napoletană), fiind interpretate identic sau diferit (vezi Ramat \& Ricca, 2016, p. 61). Trebuie însă făcută remarca că nicăieri ca în româna nord-dunăreană fenomenul nu a luat o așa de mare extindere și regularitate.

În concluzie, pentru română, în cazul femininelor, -uri funcționează predilect cu rol lexical, fiind legat de radicale 'masive" , în timp ce, pentru substantive din clasa neutrelor, finalul -uri (sau secvența de flective $-u r+-i^{8}$ ) funcționează predilect gramatical, marcînd pluralul (tipul joc - jocuri, loc - locuri, lucru - lucruri, tablou - tablouri) și numai, izolat, în raport cu radicale masive (arginturi, metaluri, vinuri), funcționează și lexical.

\section{Substantive abstracte}

\subsection{Trăsături caracteristice}

Ca și cele masive, substantivele abstracte se disting, flexionar, prin apartenența la clasa non-numărabilelor, iar, morfosintactic, prin utilizarea de preferință în structuri argumentale fără articol (articol 'zero'). Ambele caracteristici sînt prezente încă din româna veche.

\subsection{Substantive abstracte pluralizate (tipul „cinste”, „miloste”)}

S-a semnalat deja bogăția de formații abstracte a limbii române în general și a românei vechi în special (FCLRV; Pană Dindelegan, 2017), rezultată, printre altele, și din inventarul bogat de sufixe abstracte, din productivitatea mare a multora dintre ele, din situațiile de sinonimie și de concurență.

În acest cadru, remarcăm caracteristica limbii române vechi de 'pluralizare' frecventă a abstractelor: în locul unor utilizări singularia tantum, caracteristice românei actuale, substantivele abstracte apar frecvent

\footnotetext{
${ }^{7}$ Fără să aibă aceeași extindere, o utilizare asemănătoare apare în cazul formelor feminine de plural în „-(a)le”: tipul cosmeticale, istericale, mitologicale, politicale, zaharicale (Pană Dindelegan, 2009, p. 19), unde finalul -(a)le, pe lîngă asocierea cu valoarea „feminin plural”, este purtător şi de valoare lexicală suplimentară, atribuind formației conotaţii depreciative, ironice. Procesul este asemănător, constînd în convertirea unui semn de plural într-unul lexical.

${ }^{8}$ Tipul de analiză „timp-ur-i” este prezentat în Maiden (2016a,b) și permite detaşarea a două morfeme distincte de plural: -ur-şi -i, ambele exprimînd „femininul”. Soluția lui Maiden (2016a,b) ține seama de realitatea istorică, potrivit căreia, în secolul al XVI-lea, în complexul-flectiv „-ure”, desinența de plural - $i$ înlocuiește desinența mai veche - $e$ (-ure > -uri: timpure > timpuri). Modificarea -e > -i urmează același curs de modificări întîlnit și la alte feminine (plurale precum bălți, boli, gropi, răni, roți, tălpi s-au impus în locul mai vechilor balte, boale, groape, rane, roate, talpe și numeroase alte forme non-standard de tipul băniți, catarămi, crătiți, făbrici, hăini, înghețăți circulă paralel cu formele mai vechi standard în -e). Marcarea dublă a pluralului, prin mărci flexionare coocurente, vine în sprijinul ideii că pluralul românesc este „supramarcat” sau că este caracterizat prin ceea ce se numește „extended exponence”; asta înseamnă că marcarea pluralului nu se limitează la desinență, ci întrepătrunde și radicalul, făcînd ca segmentarea să fie, de aceea, foarte dificilă.
} 
cu formă de plural $^{9}$ (vezi și Frâncu, 2009, p. 28). Pentru formațiile cu corespondent slav, s-a propus ca explicație și „modelarea după forma de plural a cuvintelor slave corespunzătoare” (Candrea, 1916, p. CLXXXII).

Nu o dată, abstractele pluralizate apar în cascadă; vezi (8), Chivu (1993, p. 176).

(8) a. Carile sînt năravurile trupulu<i> ceal<ea> realele? Măriile, trufele, mîniile, uciderile, curviile (...), saltăturile (...), urgiile, clevetele (cs.1609-18, 114 ${ }^{\mathrm{v}}$ )

b. Nuspunem strîmbătățile (...), clevetirile, voile veghiiate [„părtiniri”], fățăriile, mozaviriile [„calomnii”], vînzärile și pîrăle ce facem unul altuia (AD.1722-5, 85²)

Forma de plural este fie identică cu cea de singular, deci o situație de invariabilitate (sG EPL blîndeațe, $\mathrm{SG} \equiv \mathrm{PL}$ cinste, $\mathrm{SG} \equiv \mathrm{PL}$ datoare „datorie”, $\mathrm{SG} \equiv \mathrm{PL}$ dragoste, $\mathrm{SG} \equiv \mathrm{PL}$ pace $(9 \mathrm{a}-\mathrm{g})$, fie diferită de a singularului, după tiparul substantivelor feminine cu singularul în - e [cinste - cinsti, foamete - foameți, miloste - milosti, năpaste - năpăștil/năpasti, pace - paci, ruşine - rușini (10a-o)] sau al celor feminine cu singularul în -ă și pluralul în -e [măreață „măreție” - măre(a)țe, sfadă - sfade, slavă - slave (11a-c)] sau în -i [pîră - pîri,

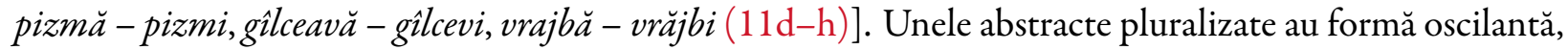
apărînd, în contextele de plural, fie ca invariabile, fie cu formă diferită de SG (PL cinste // cinsti, PL dragoste // dragosti, PL pace // paci, PL pizme // pizmi).

(9) a. Ascultați, oameni iubitori la oameni, adînculșiblîndeațele ${ }^{10}$ ce feace Dumnedzău (CLRV.1621$33,195 / 170^{\mathrm{r}}$ )

b. ca să te ajute cu bani și cu alte multe cinste (Dî.1600, XXXII)

c. Unde-s cinstele ceale de frunte? (Mărg.1691, 145 )

d. vor inpărți cinstele (FN.1693-704, 167)

e. pentru dragostele muierești (Cron.1689, 27)

f. Doamne, miluiaşte noi cu pacele tale (CL.1570, $8^{\mathrm{r}}$ )

g. nu iaste mai bună decîtu pacele și dragostele $\left(\mathrm{CC}^{2} .1581,129 / 33\right)$

(10) a. cu multe cinsti cinstiră (cv.1563-83, 49v)

b. şi-i făcea trei cinsti şi trei ruşini (FD.1592-604, 599 $\mathrm{r}$ )

c. la alte cinsti (PA 1630, CAP.250)

d. mai sus (...) decit toate cinstile (DPar.1683, III/98 ${ }^{\mathrm{r}}$ )

e. Laudele părinților și cinstile (Mărg.1691, $4^{\mathrm{v}}$ )

f. färă alte cinsti (FN.1693-704, 203)

g. î sînt acestea necinsti (FN.1693-704, 376)

h. vorfifoameți șigriji ( С T.1560-1,99 $)$

i. Lăsa-voiu pre voi omet și geru greu și foameți și pară (CLRV.1621-33, 195/171 v)

j. plinră de milosti (Cv.1563-83, 63 ${ }^{\mathrm{v}}$ )

k. și mai mare năpăşsti ne face (Dî.1599, XVIII)

1. cîndu întru näpasti (...) cădeți (cV.1563-83, 55 $\left.{ }^{\mathrm{r}}\right)$

m. să lăsați (...) paci și tocmeale bune (Dî, CIII)

n. Pacile lumiei tale dăruiaşte besearecilor tale (CL.1570, 42 ${ }^{\mathrm{v}}$ )

o. s-au prinsu la niscare rușini (Mărg.1691, 1v)

(11) a. Cine iubeaște măreațele easte rob jucătorilor (FD.1592-604, 576 ${ }^{\mathrm{r}}$ )

b. Și începu fratele a face sfade cu starețul, dosădindu-l și zî̀înd (DVs.1682-6, 56 ${ }^{\mathrm{v}}$ )

c. le făgăduesc mari slave și cinsti (FN.1693-704, 52)

d. să lepădăm de la noi toate răutățile, toate pizmile (CLRV.1621-33, 193/191 ${ }^{\mathrm{r}}$ )

e. avînd Vladulpîrcălabul pîri și gîlcevi cu Stoica logofătul (D RH,B.1645, XXX)

\footnotetext{
${ }^{9}$ De remarcat că toate substantivele abstracte de sub (9)-(11) nu mai apar, în româna actuală standard, cu formă de plural.

${ }^{10}$ Intră aici și celelalte formații cu sufixul abstract $-e(a)$ țe: SG $\equiv \mathrm{PL}$ bătrîneațe, tinereațe.
} 
f. la clevete, la zavistii, la vrăjbi și goniri (AIP.1705, $4^{\mathrm{r}}$ )

g. de faptele sale cu amestecaturile ce avuse cu Racotiii? (CLM.1700-50, 295 ${ }^{\mathrm{v}}$ )

h. Că pe acea vreme ave gîlcevi $c u$ şfedzii (NL 1750-66, 44)

Pluralele, atunci cînd apar, se dezambiguizează fie prin selecția unei anumite forme de articol (blîndeațele, cinstele, dragostele, pacile), fie prin acordul cu un adjectiv propriu-zis, un cuantificator, un demonstrativ sau un posesiv, cărora le impune forma de feminin plural (multe cinste, toate cinstile, dragostile muierești, pacile tale).

În ce privește forma de GEN-DAT.SG a substantivelor abstracte feminine, aceasta, încă din limba veche,

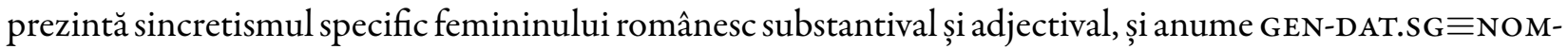
ACC-GEN-DAT.PL. Cum pluralul acestor substantive, atunci cînd se folosește, este oscilant, și forma de GEN-DAT.SG reflectă aceeași variație de la plural, genitiv-dativul apărînd fie ca invariabil ${ }^{11}$ [(12a-b): cinste(i)], fie cu formă variabilă, sincretică cu pluralul [(12c-d): cinsti $(i) ;(12 \mathrm{e})$ : foameți(ei)].

(12) a. unii dulceți și unii cinste $\left(\mathrm{CC}^{2} .1581,319 / 17\right)$

b. mărirea aceștii cinste (Mărg.1691, 64 )

c. te aleasă Dumnedzău și te spodobi aceștiia cinsti (FN.1693-704, 371)

d. te-au spodobit (=a considera demn) cinstii aceștiia a firea impărat (FN.1693-704, 376)

e. anii foameției (Po.1582, 112)

Frâncu (2009, p. 28) observă că, deși prezente în tot felul de texte, formele abstracte pluralizate au frecvență mai mare în „variantele nordice”. Numai în CV.1563-83, de exemplu, apar următoarele abstracte pluralizate, multe dintre formele în discuție dispărînd ulterior din limbă; vezi exemple precum: PL lăsăciuri 'iertare' (CV.1563-83, 39/6); PL urăciuri(le) 'binecuvîntare' (CV.1563-83, 62 /14); PL clevete(le)

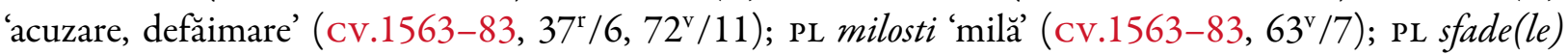
'ceartă' (CV.1563-83, 63 /14); PL strasti 'patimă (CV.1563-83, 70v/14); mîniicii(le) 'dezmăț' (cv.156383, 79 /12; < mîniac; apud Costinescu, 1981, p. 190); pîşsenii(le) 'trufie' (cv.1563-83, 65 /14; < pî̀ssen 'trufaş'; apud Costinescu, 1981, p. 192); scîrbi 'suferință' (cv.1563-83, 70 /10, 75\% /5).

În româna modernă standard, formele pluralizate ale substantivelor abstracte sînt mult mai puțin folosite, substantivele comportîndu-se ca singularia tantum, astfel că situația de invariabilitate de sub (9) nu apare decît pentru singular (vezi formele recomandate de $\mathrm{DOOM}^{2}$ : cinstei, foamei, foametei, onoarei, setei). Și dacă se folosesc la plural, pluralizarea se asociază cu diverse sensuri concrete și chiar cu modificări de gen (vezi onoare vs $_{\mathrm{F}}$ onor $_{\mathrm{N}}-$ onoruri $_{\mathrm{N}}$ ).

\section{Pluralizarea tipului colectiv ,zestre”}

Substantiv colectiv, de origine latinească (< DEXTĔR $Æ$; Ciorănescu, 2003, p. 853), apare în pravilele secolului al XVII-lea cu forme sincretice pentru ambele numere [(13a) vs (13b)], predominante fiind aparițiile de plural (13b-d); vezi distribuția pe forme de număr în tabelul următor. Recunoașterea singularului sau a pluralului se face adesea contextual, prin selecția unei forme specializate de articol (dzeastrele) sau prin acordul cu adjective de diverse tipuri (altă dzeastre vs aceale dzeastre).

(13) a. să nu mai ceară altă dzeastre SG $_{\mathrm{SG}}(\mathrm{PA} 1630,570)$

b. nu va lua nemică dentr-aceale dzeastre $e_{\mathrm{PL}}$ (Prav.1646, 113/27)

c. să-şi ia şi dzeastrele ${ }_{\mathrm{PL}}$ toate cîte va fi avut (PA 1630, 511)

d. să-și piardză muiarea toate dzeastrele ${ }_{\mathrm{PL}}$ ce va fi avînd (Prav.1646,110/3)

\footnotetext{
${ }^{11}$ În cazul formelor articulate, sincretismul NOM-ACC.SG vs. GEN-DAT.SG se rezolvă prin articolul enclitic (cinstea - cinstei).
} 


\begin{tabular}{cccc} 
Text & $d$ zeastrele F.PL & $d$ zestre(a) F.SG & $\begin{array}{c}\text { dzestre AMBIGUU } \\
\text { (sG sau PL?) }\end{array}$ \\
\hline PA 1630 & 41 & 1 & 10 \\
Prav.1646 & 30 & 3 & 2
\end{tabular}

Tabela 1: Formele de plural ale substantivului zestre

După mai mult de un secol, în Prav.1780, predominante sînt formele de singular (singularul unui colectiv): 8 atestări ale formei articulate de feminin zestrea/zestria (14a), 5 ale formei de feminin fără articol, dezambiguizarea ca singular realizîndu-se prin acord (14b), 5 forme de GEN-DAT.SG zestrii/zestriei (14c) și numai o singură formă de plural $(14 \mathrm{~d})$. Forma de plural și formele de GEN-DAT.SG indică diferențierea formei de PL (zestre - zestri). Pentru româna actuală standard, $\mathrm{DOOM}^{2}$ nu indică și pluralul, ceea ce înseamnă utilizarea ca singulare tantum.

(14) a. multumită pe zestrea ce va fi luat (Prav.1780, 98/27)

b. s-au multumit pe acea zestre (Prav.1780, 94/6-7)

c. cîte lucruri de ale zestri să vor găsi (Prav.1780, 94/17)

d. cheltuielele zestrilor (Prav.1780, 96/1).

\section{Concluzii}

- Fenomenul pluralizării substantivelor masive, abstracte și colective este extrem de frecvent în româna veche.

- Pluralizarea masivelor și a abstractelor antrenează, adesea, modificarea sensului, determinînd, în cazul masivelor, „demasificarea”, iar, în cazul abstractelor, „dezabstractizarea” / „concretizarea”.

- Dacoromâna și-a specializat o desinență (-uri) pentru pluralizarea masivelor și, implicit, pentru modificarea sensului.

- Evoluția lui -uri (atît din pluralul femininelor - tipul mătăsuri, verdețuri, cît și din pluralul neutrelor - tipul metaluri, vinuri) evidențiază un proces de tip special, constînd în convertirea unui semn gramatical (de plural) într-unul lexical.

- Simultan, are loc și ambiguizarea mărcii -uri, care ajunge să exprime, cumulativ, două valori: una gramaticală (de plural) și una lexicală (derivativă).

\section{Bibliografie}

\section{A. Corpus}

A.1620 = Alexandria, în Zgraon, Fl. (ed.), Cele mai vechi cărțipopulare în literatura română, vol. 11, Fundația Națională pentru Știință și Artă, București, 2006.

AD.1722-5 = Antim Ivireanul, Didabii, în Opere, ed. G. Ștrempel, Editura Minerva, București, 1972.

AIP.1705 = Antim Ivireanul, Învățătură pentru taina pocăinții, în Opere, ed. G. Ștrempel, Editura Minerva, București, 1972, p. $347-351$.

вв.1688 = Biblia adecă Dumnezeiasca Scriptură a Vechiului și Noului Testament, tipărită întîia oară la 1688 în timpul lui Șerban

Vodă Cantacuzino, Domnul Țării Românești, Editura Institutului Biblic, București, 1977.

CazV.1643 = Varlaam, Cazania, ed. J. Byck, Fundația Regală pentru Literatură și Artă, București, 1943.

CBuc.1749 = Carte întru carea să scriu minncările, ed. I. Constantinescu, Editura Fundației Culturale Române, București, 1997.

$\mathrm{CC}^{1} .1567=$ Coresi, Tîlcul evangheliilor și molitvenic românesc, ed. V. Drimba, Editura Academiei, București, 1998.

$\mathrm{CC}^{2} .1581$ = Coresi, Cartea cu învățătură, ed. S. Pușcariu \& Al. Procopovici, Atelierele Grafice Socec, București, 1914.

CDicț.1691-7 = Teodor Corbea, Dictiones latina cum valachica interpretatione, ed. A.-M. Gherman, Editura Clusium, ClujNapoca, 2001.

CL.1570 = Coresi, Liturghierul lui Coresi, ed. Al. Mareș, Editura Academiei, București, 1969.

CLM.1700-50 = Miron Costin, Letopisețul Țărîi Moldovei. Opere, ed. P.P. Panaitescu, Editura de Stat pentru Literatură și Artă, București, 1958. 
CLRV = Mareș, Al. (coord.) (2016). Crestomația limbii române vechi, vol. I (1521-1639), Editura Academiei Române, București.

Cron.1689 = Cronograftradus din grecește de Pătrașco Danovici, 2 vol, ed. G. Ștrempel, București, 1998.

cs.1609-18 = Codex Sturdzanus, ed. Gh. Chivu, Editura Academiei Române, București, 1993.

Ст.1560-1 = Coresi, Tetraevanghelul tipărit de Coresi, Brașov 1560-1561, comparat cu Evangheliarul lui Radu de la Mănicești. 1574, ed. Fl. Dimitrescu, Editura Academiei, București, 1963.

CV.1563-83 = Codicele Voronețean, ed. M. Costinescu, Editura Academiei, București, 1981.

Dî = Chivu, Gh., Georgescu, M., Ioniță, M., Mareș, Al. \& Roman-Moraru, Al. (eds) (1979). Documente și însemnări românești din secolul al XVI-lea, Editura Academiei, București.

DPar.1683 = Dosoftei, Parimiile preste an, Iași, 1683, ed. M. Ungureanu, Editura Universității „Alexandru Ioan Cuza”, Iași, 2012.

DRH,B = Documenta Romania Historica. B. Țara Românească, Editura Academiei Române, București, 1969: vol. XXII (16289); 1974: vol. XXIV (1633-4); 1985: vol. XXV (1635-6); 1998: vol. XXX (1645); 2003: vol. XXXI (1646).

DPV.1673 = Dosoftei, Psaltirea în versuri, în Dosoftei, Opere, 1, Versuri, ed. N. A. Ursu, Mitropolia Moldovei și a Sucevei, Iași, 1974.

Dvs.1682-6 = Dosoftei, Viața și petrecerea sfinților, ed. R. Frențiu, Editura Echinox, Cluj-Napoca, 2002.

Ev.1642 = Evanghelie învățătoare, Govora, ed. A.-M. Gherman, Editura Academiei, București, 2011.

FD.1592-604 = Floarea darurilor, în Roman Moraru, Al. (ed.) (1996). Cele mai vechi cărți populare în literatura română, 1 , Editura Minerva, București.

FN.1693-704 = Foletul Novel. Calendarul lui Constantin Vodă Brîncoveanu (1693-1704), ed. E. Vîrtosu, Monitorul Oficial și Imprimeriile Statului, București, 1942.

Mărg.1691 = Ioan Gură de Aur, Mărgăritare, ed. R. Popescu, Editura Libra, București, 2001.

NL 1750-66 = Ion Neculce, Letopisețul, în Ion Neculce, Letopisețul Țării Moldovei și O samă de cuvinte, ed. I. Iordan, Editura de Stat pentru Literatură și Artă, București, ed. a II-a, 1959.

PA 1630 = Eustratie Logofătul, Pravila aleasăa, ed. A.-M. Gherman, Editura Academiei Române, București (sub tipar).

Po.1582 = Arvinte, V., Caproșu, I. \& Gafton, Al. (eds) (2005). Palia de la Orăştie, vol. 1, Textul, Editura Universităţii „Alexandru Ioan Cuza”, Iași.

Prav.1646 = Carte românească de invățătură, 1646, ed. A. Rădulescu, Editura Academiei, București, 1961, p. 33-106.

Prav. 1780 = Pravilniceasca condică, 1780, ed. A. Rădulescu, Editura Academiei, București, 1957.

\section{B. Referințe}

Avram, M. (2003-2004). Despre desinența - uri la substantivele feminine, în „Analele Universității «Alexandru Ioan Cuza»”, t. XLIX-L, Studia linguistica et philologica in honorem D. Irimia, p. 63-70.

Candrea, I.-A. (1916). Psaltirea Scheiană, I, Introducerea, Atelierele Grafice Socec, București.

Chivu, Gh. (1993). Studiu introductiv la Codex Sturdzanus, Editura Academiei Române, București.

Ciorănescu, A. (2002). Dicționarul etimologic al limbii române, Editura Saeculum I.O., București.

Costinescu, M. (1981). Codicele Voronețean, ediție critică, studiu filologic și studiu lingvistic, Editura Minerva, București.

Doom $^{2}=$ Dicționarul ortografic, ortoepic și morfologic al limbii române, Editura Academiei Române, București, 2005.

FCLRV = Popescu-Marin, M. (coord.) (2007). Formarea cuvintelor în limba română din secolele al XVI-lea - al XVIII-lea, Editura Academiei Române, București.

Frâncu, C. (1982). Vechimea și difuziunea lexicală a unei inovații comune dialectelor limbii române: desinența-uri la pluralul femininelor, în „Limba română, XXXI, 3, p. 199-212.

Frâncu, C. (2009). Gramatica limbii române vechi, Casa Editorială Demiurg, Iași.

GR = Pană Dindelegan, G. (ed.) (2013). The Grammar of Romanian, Oxford University Press, Oxford.

Maiden, M. (2014). Le rôle de la synonimie lexicale dans formation du pluriel flexionnel en daco-roman, în "Mémoires de la Société de Linguistique de Paris. Série tome XXII. Morphologie flexionnelle et dialectologie romane: typologie(s) et modélisation(s)", Peeters Publishers, Leuven, p. 35-50.

Maiden, M. (2015). The Plural Type cărnuri and the Morphological Structure of the Romanian Feminine Noun in Diachrony, în Pană Dindelegan, G., Zafiu, R., Dragomirescu, A., Nicula, I., Nicolae, A., Esher, L. (eds), Diachronic Variation in Romanian, Cambridge Scholars Publishing, Newcastle, p. 33-52.

Maiden, M. (2016a). Ambiguity in Romanian Word-Structure. The Structure of Plurals in -uri, în „Revue roumaine de linguistique", LXI, 1, p. 3-12.

Maiden, M. (2016b). Segmentarea cuvintelor în teoria morfologică și problema pluralelor românești în-uri, în Constantinescu, M., Dragomirescu, A., Nicolae, Al., Stoica, G., Zafiu, R. (eds), Perspective diacronice și comparative asupra limbii române, Actele celui de al XV-lea Colocviu Internațional al Departamentului de Lingvistică, Editura Universității din București, București, p. 11-7.

Nedelcu, I. (2013). Singularia tantum and pluralia tantum, în GR, p. 260-261.

Pană Dindelegan, G. (2009). Trăsături flexionare ale substantivului în româna actuală, în Pană Dindelegan, G. (coord.), Dinamica limbii actuale, Editura Academiei Române, București. 
Pană Dindelegan, G. (2016a). The partitive phrase, în sor, p. 323-332, Crossref.

Pană Dindelegan, G. (2016b). Substantive invariabile și istoria lor, în Sala, M., Stanciu Istrate, M. \& Timotin, E. (eds), Pagini alese. Omagiu domnului Alexandru Mareș la împlinirea vîrstei de 80 de ani, Editura Univers Enciclopedic Gold, București, p. 164-178.

Pană Dindelegan, G. (2017). Caracteristici ale sufixelor abstracte în limba română, volum omagial Maria Cătănescu (sub tipar). Ramat, P. \& Ricca, D. (2016). Romance: a typological approach, în Ledgeway, A. \& Maiden, M. (eds), The Oxford Guide to the Romance Languages, Oxford University Press, Oxford, p. 50-62, Crossref.

soR = Pană Dindelegan, G. (ed.) (2016). The Syntax of Old Romanian, Oxford University Press, Oxford, Crossref. 